\section{HAPPENING ART DALAM AKSI \\ DEMONSTRASI MASSA DI YOGYAKARTA}

\section{Trie Wahyuni}

\section{FBS Universitas Negeri Yogyakarta}

Abstract
This study is aimed at identifying the forms and the purpose of happening art performance in mass demonstration frequently taking place nowadays. The subject of the study is the primary resources, namely the mass demonstration agents consisting of the activators, the performers and the supporters, as well as the viewers or the society in Yogyakarta watching the performance in the demonstration. The data were collected through observation, documentation, literature and interviews. The study shows that the form of the happening art performance consists of some elements like: 1) duration, 2 ) herformers 3) poke-up, 4) costume, 5) stage, 6) property, 7) dace duration, 2 and 9) verbal expresion. to make the demonstration easy to be understood by the society.

Key Words: happening art, mass demonstration

\section{A. Pendahuluan}

\section{Latar Belakang}

Aksi demonstrasi massa yang telah dilakukan selama ini merupakan fakta sejarah yang tidak dapat dihindari. Keberadaannya sangat dibutuhkan karena dapat digunakan untuk mengingatkan adanya kekurangberesan serta dapat dijadikan picu untuk menentukan adanya gerak perubahan. Selama kasus-kasus yang telah disebutkan di atas belum bisa terwujud, sewaktu-waktu demonstrasi akan muncul. Hal itu dilandasi pemikiran, jika kasus-kasus seperti itu hanya dibicarakan dalam forum diskusi, seminar, pengajian, ditulis dalam surat kabar, akan teramat sulit diketahui hasilnya. Satu-satunya pilihan yang dapat digunakan untuk menekan pihak yang menurut para demonstran sewenang-wenang, dholim, arogan, mau menang sendiri, adalah dengan melakukan aksi demonstrasi massa. Terlebih jika kesewenang-wenangan dan seterusnya tadi makin menggejala dan kesenjangan sosial makin melebar, sementara itu jalur resmi yang ada tidak mampu menembus sampai ke akar persoalan, tentu aksi demonstrasi yang akan dipilih untuk melakukan perlawanan.

Aksi demonstrasi massa yang terjadi di Yogyakarta, terutama yang berlangsung akhir-akhir ini, cukup marak. Hampir setiap bulan masyarakat Yogyakarta dapat menyaksikan aksi demonstrasi massa, terutama yang berlangsung di Bunderan Universitas Gadjah Mada (Bulaksumur), Perempatan Kantor Pos Yogyakarta, dan Pelataran Gedung DPRD DIY. Yang menarik dari berbagai aksi demonstrasi massa tersebut, adalah sering ditampilkannya peragaan atau pertunjukan sebagai media ekspresi, yaitu happening-art $(h-a)$.
Karena dengan gambar suatu pesan dapat disampaikan secara cepat dan jelas dari pada penjelasan yang bersifat verbal. Matakuliah direksi adalah matakuliah bersifat praktik yang memerlukan pemandu untuk dapat menguasai dengan baik. Berbeda dengan pelajaran praktik instrumen yang memungkinan mahasiswa pemula dapat mengontrol ketepatan nada, pada matakuliah direksi kesalahankesalahan gerakan sulit dideteksi oleh mahasiswa yang bersangkutan.

Hadirnya seorang model yang memberi contoh akan memudahkan bagi mahasiwa untuk melakukan gerakan-gerakan aba-aba yang tepat. Namun untuk dapat memimpin lagu dengan baik tidak cukup hanya mengandalkan gerakan aba-aba yang benar, dirigen harus menguasai lagu yang dibawakan termasuk dalam segi harmonisasi lagu, sehingga apabila terdapat intonasi yang kurang tepat dinyanyikan oleh para anggota sesuai dengan pembagian suara masingmasing dirigen mampu mengingatkan dan membentulkan. Pendokumentasian aransemen lagu dengan program encore dan midi mampu memberikan contoh lagu dengan tepat dan jelas termasuk dalam hal harmonisasi. Dengan mendengarkan contoh lagu secara berulang-ulang memungkinan mahasiswa untuk menguasai secara tepat.

Program midi dan encore mampu memberikan contoh nada dan ritme secara tepat, namun kurang dapat menggambarkan ekspresi secara dalam karena sifat komputer yang memiliki akurasi komputasi yang handal sehingga kurang dapat menggambarkan perubahan tempo dan dinamik secara baik sebagaimana bila dirigen handal yang melakukan. Untuk itu diperlukan adanya media pendukung lain untuk meningkatkan prestasi belajar direksi, salah satunya adalah menyediakan contoh dirigen dalam berbagai pola gerakan yang dikemas dalam bentuk VCD

Penggunaan multimedia terpadu ini dapat meningkatkan proses pembelajaran karena mahasiswa mendapat kesempatan berinteraksi secara bebas dengan kegiatan dirigen tanpa harus selalu konsultasi dengan dosen. Dengan media tersebut memungkinkan mahasiswa untuk menyaksikan proses gerakan aba-aba secara berulang-ulang, mendengarkan lagu yang dinyanyikan dengan pembagian suara, dan membandingkan berbagai pola gerakan.

Penggunaan multimedia terpadu memungkinan dosen menjangkau sasaran mahasiswa dalam jumlah yang lebih besar, dan memberi kemungkinan mahasiswa belajar sesuai dengan minat, kemampuan dan kecepatan masingmasing. Berdasarkan uraian tersebut, maka dalam penelitian ini diajukan hipotesa "Penggunaan multimedia terpadu pada proses pembelajaran dapat meningkatkan pretasi belajar direksi".

\section{B. Metode Penelitian}

Pelaksanaan penelitian meliputi dua tahap, yaitu kegiatan pra penelitian dan kegiatan penelitian. Kegiatan pra penelitian adalah pembuatan multi media 
dengan analisis mengenai dampak lingkungan (amdal), dan sebagainya.

Problem-problem sosial itu membuat kalangan muda tergerak untuk bangkit menentukan sikap, mengingat masyarakat yang tertindas akibat kebijakan timpang itu umumnya tidak/kurang berani angkat bicara atau cenderung diam. Kalangan muda merasa terpanggil untuk mengungkapkan gugatan atas ketidaksetujuan mereka. Gugatan itu merupakan bentuk kesadaran moral dan sikap solidaritas mereka terhadap masyarakat luas yang tertindas.

Gugatan ketidaksetujuan itu sering diekspresikan oleh kalangan muda dalam bentuk aksi demonstrasi yang melibatkan massa dalam jumlah yang relatif besar. Aksi demonstrasi sesungguhnya hanyalah salah satu cara untuk melampiaskan gugatan ketidaksetujuan (Cahyadi, 1994: 83-86). Jika sekarang ini, aksi demonstrasi menjadi mekanisme yang dipandang sangat efektif oleh kalangan muda untuk mengekspresikan gugatan ketidasetujuan, mekanisme tersebut dilakukan berdasarkan pertimbangan secara rasional sebagai berikut.

Pertama, suatu pilihan cara tidak dapat dilepaskan dari tujuan yang ingin dicapai. Demonstrasi dipilih karena dipandang sebagai cara yang paling efektif dan memadai untuk bisa mencapai tujuan. Tujuan yang dicita-citakan adalah perubahan, perubahan kebijakan, atau perubahan sikap dalam menerapkan kebijaksanaan. Tujuannya bukan hanya ungkapan sikap kritis dalam menganalisis situasi masyarakat. Kalau yang diharapkan hanya sekedar penanaman sikap kritis secara batiniah dan personal, tujuan tersebut dipandang cukup dapat dicapai dengan studi dan diskusi kelompok saja. Karena yang diharapkan adanya suatu perubahan, maka media yang dipilih haruslah media yang bisa menunjukkan keseriusan atas masalah yang digugat dan banyaknya massa yang menggugat. Demonstrasi dipandang sebagai media yang memadai untuk menyatakan hal tersebut. Tuntutan akan adanya suatu perubahan dinantikan wujudnya dalam bentuk aksi, yang dari sana diharapkan akan muncul reaksi sebagai tanda adanya responsi. Gerakan atau aksi kemasyarakatan merupakan bentuk tingkah laku kolektif yang berpengaruh pada sugestibilitas, ketularan, dan kepatuhan kelompok terhadap seorang pemimpin. Gerakan yang dibangun melalui tingkah laku kolektif akan menghasilkan kekuatan besar yang mampu membawa perubahan (Mirsel, 2004: 36-37).

Kedua, jika protes itu dilakukan secara halus dan sopan, sering hanya dianggap sebagai sindiran. Sindiran kadang-kadang hanya dihadapi dengan senyum atau tawa, ditanggapi sebagai layaknya dhagelan Mataram. Menulis kritik di surat kabar belum tentu dimuat. Kalaupun dimuat, biasanya itu hanya dibaca sambil lalu, sebagai bacaan sambilan ketika makan pagi atau sambil bermobil berangkat ke kantor. Kalaupun dibicarakan, seringkali itu hanya menjadi diskusi kecil. Kalau kritiknya dirasakan menyentil, sering itu hanya dirasakan sebagai suatu cubitan kecil yang tidak menyakitkan. Jika mengadu ke wakil rakyat atau instansi Pemerintah, hampir selalu dihadapi dengan gaya 'bapak yang merasa pembelajaran mencakup semua sumber yang diperlukan untuk melakukan komunikasi dengan mahasiswa. Selanjutnya Degeng ( 2001 : 7 ) menjelaskan bahwa media dapat mengatasi gangguan-gangguan komunikasi karena verbalisme, salah tafsir, perhatian ganda, pembentukan persepsi tak bermakna, dan kondisi lingkungan yang tidak menunjang.

Berdasarkan uraian pada bagian syarat dirigen dapat dikatakan bahwa seorang dirigen secara musikal harus memiliki pendengaran yang baik, sedangkan pada bagian teknik aba-aba mengungkapkan bahwa seorang dirigen harus mampu melakukan gerakan aba-aba yang tepat. Media yang tepat untuk meningkatkan pendengaran adalah media audio, sedangkan media yang tepat menggambarkan pola gerakan adalah media visual. Media audio yang dapat digunakan untuk meningkatkan kepekaan pendengaran adalah media tape recorder dan komputer multi media.

Kemajuan di bidang komputer telah menyediakan seperangkat media audio yang banyak membantu kepekaan pendengaran musik. Antara lain adalah program encore yang mampu memperdengarkan nada dan menvisualkannya dalam notasi musik. Selain itu komputer juga mampu memperdengarkan lagu dengan program midi.

Media komputer ini dapat digunakan untuk meningkatkan kepekaan musikal dirigen baik meliputi unsur nada maupun ritme, karena komputer dapat memperdengarkan nada dan ritme secara tepat. Hal ini sesuai dengan pendapat Hamron (Istiyono, 2003 :251) yang menyatakan bahwa komputer mempunyai kemampuan yang cepat dan handal dalam komputasi.

Dengan demikian dalam pembelajaran direksi komputer dapat digunakan untuk meningkatkan kepekaan nada dan ritme melalui program MIDI atau encore. Selain itu komputer dapat juga digunakan untuk menvisualisasikan gerakan abaaba. Salah satu program yang mampu menvisualisasikan adalah power point. Kemampuan animasi power point dapat digunakan untuk menjelaskan urutan gerakan aba-aba.

Memberi aba-aba dalam musik merupakan perpaduan antara kegiatan mendengarkan dan melihat, dengan demikian selain diperlukan media audio dan media visual yang terpisah diperlukan juga media audio visual yang mampu menampilkan musik dan gerakan aba-aba, untuk itu diperlukan media audio visual yang mampu menggambarkan secara jelas tentang teknik menjadi dirigen. Media yang dapat dikembangkan untuk menvisualisasikan sekaligus memperdengarkan musik adalah media video dan VCD. Mengingat bahwa perkembangan teknologi VCD lebih praktis dan mudah didapat dan digandakan maka dalam penelitian ini yang dikembangkan adalah pembuatan media dalam bentuk VCD.

\section{c. Aplikasi Multi Media Terpadu pada Matakuliah Direksi}

Komponen utama yang harus dimiliki dirigen adalah kepekaan terhadap nada dan ritme, sikap (posisi) dirigen, pola gerakan, dan ekspresi. Kepekaan 
perubahan.

Hampir semua aksi demonstrasi yang terjadi di Yogyakarta dilakukan atau dimotori oleh para mahasiswa. Padahal gerakan mahasiswa di Indonesia selama ini dalam membela atau memihak rakyat yang tertindas tampaknya selalu mendapatkan ganjalan. Refleksi dan munculnya kritik semakin menyadarkan mereka bahwa untuk melakukan perubahan, misalnya perubahan politik, perlu dibangun kerjasama yang lebih luas dengan kekuatan politik di luar kekuasaan. Oleh karena itu, karakter intelektual gerakan mahasiswa perlu segera dibongkar dan format gerakan harus diubah supaya benar-benar menjadi sebuah gerakan massa (Naipospos, 1996: 17). Jadi, para mahasiswa terjun dalam sebuah aksi kekuatan tidak dengan mempergunakan identitas mahasiswa sebagai kekuatan politik tersendiri, melainkan aksi yang mengatasnamakan massa.

\section{b. Happening Art}

Fildman dalam tulisannya Art As Image and Idea (1967: 339-340) menyatakan bahwa kata happening, yang kemudian menjadi $h$ - $a$, merupakan peristiwa seni kontemporer yang dipertunjukkan sebagai ungkapan perlawanan atau pemberontakan secara visual di depan umum.

Untuk mengidentifikasi bentuk $h$ - $a$, dapat diperhatikan hal-hal berikut: (1) bahan/barang yang digunakan, (2) bentuk seninya dibuat artistik/ cantik, baik modern maupun tradisional, (3) aspek kreasi dipandang penting, (4) ada kesan humor tetapi mengandung makna dan nilai tujuan, (5) absurd, (6) dibuat janggal antara bentuk seni dan realitas kehidupan, dan (7) fantastis.

Presiden Amerika Serikat, George W. Bush, ketika berkunjung ke Australia pada 2004 didemo oleh masyarakat Australia dalam jumlah massa yang amat besar, sekitar 10.000-an orang, dengan cara turun ke jalan. Salah satu aspek yang menarik dari aksi demonstrasi massa itu adalah dipertunjukkannya $h-a$. Dalam $h-a$ tersebut diperagakan dua tokoh nomor satu dari dua negara, yakni Presiden Amerika Serikat (George W. Bush) dan Perdana Menteri Australia (John Howard). Masing-masing mengenakan setelan jas lengkap berdasi. Wajah dua orang tokoh itu divisualkan dengan memakai topeng yang menggambarkan wajah Bush dan wajah Howard.

Di situ pertunjukan teater sebagai simbol aksi demonstrasi rakyat Australia berlangsung dengan menggelar adegan Howard yang berjalan mbrangkang (merangkak), lehernya diikat dengan tali, talinya dikendalikan oleh Bush. Hal itu menggambarkan bahwa negara Australia tidak berkutik terhadap tekanan-tekanan hegemoni negara superpower Amerika Serikat, sehingga ketika Presiden Bush mengajak Howard untuk bergabung dan mendukung Amerika menyerang Irak, Howard tidak dapat berbuat apa-apa kecuali patuh.

$H-a$ yang ditampilkan dalam aksi demonstrasi massa di Australia tersebut cukup menyentuh hati, dan ternyata peristiwa ini ditayangkan oleh televisi dari seluruh dunia. Aksi demonstrasi itu merupakan protes rakyat Australia yang tidak
Organ Tunggal dikhawatirkan oleh tuan rumah kalau aleknya tidak akan meriah dan para tamu undangan juga akan banyak yang tidak datang. Hal ini membuktikan pula bahwa kehadiran Organ Tunggal saat ini di Minangkabau menjadi prestise tersendiri bagi warga masyarakat Minangkabau terlepas dari apakah masyarakatnya sanggup atau tidak untuk mendatangkannya dalam acara Baralek tetapi persepsi masyarakat akan mengatakan tanpa kehadirannya dikhawatirkan alek tidak akan menjadi meriah.

\section{Fungsi Komunikasi}

Dari sudut pandang semiotika, bunyi musik yang terdengar oleh seseorang atau masyarakat dapat dipandang sebagai sebuah tanda (sign) yang memiliki makna tertentu. Makna yang diberikan setiap orang akan berbeda-beda dan tergantung bagaimana mereka menginterpretasikannya. Setiap interpretasi yang diberikan masing-masing bersifat arbirtrer, bersifat kultural atau sesuai dengan budaya yang dianut mereka. Bunyi musik Organ Tunggal yang terdengar dari tempat penyelenggaraan acara alek dapat pula dimaknai sebagai sebuah komunikasi yang disampaikan tuan rumah kepada tamu undangannya bahwa acara Baralek telah dimulai dan sebagai isyarat pula agar para tamu undangan hendaknya bersiap-siap datang ke lokasi alek tersebut walaupun secara formal mereka telah mengundang mereka melalui sebuah kartu undangan. Atau dalam makna lain bunyi musik yang terdengar oleh warga masyarakat sekitarnya dapat pula berarti bahwa tuan rumah yang menyelenggarakan acara menggunakan Organ Tunggal sebagai sarana hiburan untuk memeriahkan acara aleknya.

\section{Fungsi Integrasi Sosial}

Masyarakat Minangkabau yang terikat dalam sistim keturunan matrilinia atau menurut garis ibu dalam tata kehidupan masyarakatnya selalu menempatkan kebersamaan sebagai cerminan sosial budayanya. Kebersamaan dalam mengambil suatu keputusan menjadi ciri khas budaya yang masih bertahan sampai sekarang. Dalam kebersamaan tersebut akan terjalin suatu rasa keterikatan yang mendalam baik antar individu dengan individu maupun antar golongan atau kelompok masyarakat satu dengan kelompok masyarakat lainnya di Minangkabau. Kebersamaan terjalin dalam wujud kebersamaan antar anggota masyarakat yang satu suku ataupun antar sesama warga masyarakat yang berbeda sukunya. Dalam acara Baralek warga masyarakat yang menjadi tamu undangan tuan rumah, baik yang sesuku atau yang tidak sesuku akan bertemu dalam meramaikan suasana alek tersebut. Kehadiran pertunjukan Organ Tunggal dalam acara Baralek yang digunakan sebagai sarana hiburan utama bagi masyarakat sebenarnya juga memiliki fungsi lain atau memiliki fungsi dengan tujuan tertentu yang disebut Soedarsono (2002: 172) dengan fungsi sekunder yakni sebagai seni pertunjukan yang selain dapat memberikan hiburan pada penikmatnya di samping itu juga memiliki tujuan lainnya misalnya sebagai pengikat solidaritas kelompok masyarakat. Fungsi sekunder Organ Tunggal sebagai alat yang dapat 
Sebelum $h-a$ dipertunjukkan dalam suatu aksi demonstrasi, terlebih dahulu diadakan latihan bersama antara pelaku (peraga) dan kesatuan kelompok yang memiliki rencana mengadakan demonstrasi massa. Dituturkan oleh Totok (aktivis HMI), latihan dilakukan di markas HMI. Antara peraga dan kelompok massa yang masing-masing diwakili fron mengadakan kesepakatan-kesepakatan bersama. Namun, menurut Sigit (mahasiswa seni rupa) dan Steffanus (mahasiswa unit teater) aktivis demonstrasi di Yogyakarta, ketika akan menyelenggarakan $h-a$, mereka tidak perlu mengadakan latihan. Yang penting antara massa demonstran dan para peraga $h-a$ sudah mengadakan kesepakatan bersama. Kesepakatan itu menyangkut elemen-elemen pertunjukan yang akan ditata dan hubungannya dengan demonstrasi massa.

Adapun elemen-elemen pertunjukan dalam $h$ - $a$ meliputi: (1) lama pertunjukan, (2) peraga, (3) rias, (4) busana, (5) panggung, (6) musik, (7) properti, dan (8) gerak.

1. Lama Pertunjukan

Lama $h$ - $a$ kadang-kadang ditentukan, ada kalanya juga tidak ditentukan oleh kelompok demonstran. Pernah terjadi $h$ - $a$ hanya dipertunjukkan dalam tempo satu menit, yaitu ketika mereka berdemonstrasi untuk menyambut kedatangan seorang Menteri di suatu kampus. Pertunjukan $h$ - $a$ ini merupakan sikap mahasiswa yang menolak kedatangan Menteri tersebut, karena dianggap sebagai campur tangan politik terhadap masyarakat kampus. Belum lama berlangsung, demonstrasi massa untuk memprotes RUUAPP (Rancangan Undang-undang Anti Pornografi dan Pornoaksi) yang dilakukan di depan Bunderan UGM, di depan kantor DPRD DIY, dan di depan Kantor Pos Besar, $h-a$ yang dilakukan oleh unsur-unsur masyarakat, seperti mahasiswa, seniman, budayawan, dalam bentuk massal menggunakan durasi pertunjukan sampai dengan satu jam bahkan lebih.

Selama ini pihak demonstran mengaku belum pernah menghitung waktu secara rinci. Namun, perkiraan secara kualitatif menyebutkan seperti telah digambarkan itu. Menurut para informan yang pernah memperagakan $h-a$, pertunjukan dapat berlangsung sebentar, tetapi dapat juga lama, bergantung pada permintaan dan kesepakatan organisasi yang menghimpun massa. Mereka menyebutkan durasi $h$ - $a$ yang pernah dilakukan berlangsung 1, 15, 30 menit, 1 jam, dan 1 jam lebih. Biasanya bila demonstrasi dilaksanakan dengan cara long march, misalnya dimulai dari Bunderan UGM sampai gedung DPRD Propinsi DIY di jalan Malioboro, $h$ - $a$ yang menyertai pertunjukannya di sepanjang jalan berlangsung dua jam, karena tampil di beberapa titik jalan, harus melakukan unjuk kebolehan dengan tujuan mendapat perhatian masyarakat umum di sepanjang jalan.

2. Peraga

Demonstrasi massa dalam bentuk apa pun bila disertai dengan $h$ - $a$ sering
Soedarsono (2002: 123) yang mengamati fungsi seni pertunjukan di Indonesia merumuskan fungsi seni pertunjukan dalam kategori fungsi primer dan fungsi sekunder. Yang dimaksud dengan fungsi primer adalah siapa yang menjadi penikmat seni pertunjukan tersebut karena pada kenyataannya seni pertunjukan memang ditujukan bagi penikmatnya. Fungsi primer terbagi tiga: (1) sebagai sarana ritual, (2) sebagai hiburan pribadi, dan (3) sebagai presentase estetis. Sedangkan fungsi sekunder menurut Soedarsono selain dapat memberikan hiburan pada penikmatnya juga memiliki tujuan lainnya misalnya: (1) sebagai pengikat solidaritas kelompok masyarakat, (2) sebagai pembangkit rasa solidaritas bangsa, 3) sebagai media komunikasi massa, (4) sebagai media propaganda keagamaan, (5) sebagai media propaganda politik, (6) sebagai propaganda program pemerintah, (7) sebagai media meditasi, (8) sebagai sarana terapi, (9) sebagai perangsang produktifitas, dsb (Soedarsono, 1999: 172). Berdasarkan penjelasan tersebut dalam melihat dan mengamati pertunjukan Organ Tunggal yang dilaksanakan dalam acara Baralek sedikitnya ada tujuh fungsi yang terdapat didalamnya, yakni: (1) fungsi sebagai ekspresi emosional, (2) fungsi sebagai hiburan pribadi, (3) fungsi sebagai simbol atau perlambang, (4) fungsi sebagai komunikasi, (5) fungsi sebagai Integrasi sosial, (6) fungsi sebagai reaksi jasmani atau perangsang produktifitas, (7) fungsi sebagai ritual adat.

1. Fungsi Ekspresi Emosional

Pada umumnya musik dapat mempengaruhi perasaan dan emosi setiap orang walaupun respon yang diberikan setiap orang ketika mendengar musik berbeda-beda antara satu dengan yang lainnya. Dari sudut pandang psikologi umum emosi adalah proses spesifik yang berorientasi untuk merespon perilaku. Emosi secara langsung selalu timbul terhadap sesuatu baik sebagai bagian dari suatu situasi atau sebagai reaksi personal. Atribut khusus yang berkaitan dengan proses penilaian emosi adalah keterlibatan personal dengan stimulus dan terjadinya perubahan perilaku terhadap stimulus itu (Djohan, 2003: 39). Menurut Merriam (1964: 219) ada pertimbangan kenyataan untuk mengindikasikan bahwa fungsi musik itu luas dan pada tingkat tertentu (khusus) dapat bermakna sebagai ekspresi emosional. Dalam pembicaraan teks lagu, kita mendapat peluang menentukan bahwa satu dari ciri-ciri alam adalah kenyataan bahwa alam menyediakan sarana bagi pengekspresian ide dan emosi yang tidak dinyatakan seperti dalam percakapan sehari-hari. Pada tingkat yang lebih umum, nampaknya musik lebih murni diliputi dengan emosi dan dinyatakan dalam ekspresi, entah emosi secara khusus atau emosi secra umum. Pertunjukan musik yang dilaksanakan dalam acara Baralek dapat pula dilihat sebagai cetusan ekspresi emosional yang dinyatakan oleh setiap orang yang terlibat didalamnya baik itu dari pemain Organ itu sendiri dalam hal ini sebagai pengiring lagunya dengan membuat beberapa kemungkinan iringan musiknya, dari para artis yang memberi hiburan dengan membawakan lagu untuk menghibur masyarakat sebagai tamu 
tersebut tidak diwujudkan dalam bentuk tokoh wayang Bethara Kala atau raksasa besar yang busananya sama dengan rias wayang wong. Tetapi, penggambaran raja serakah itu dengan memakai busana bebas atau menurut para informan bahkan asal memakai busana secukupnya.

Tata busana tersebut tidak memiliki kaidah-kaidah yang rumit karena tidak menganut format (pakem) tradisional. Bahan-bahan kostum yang dibutuhkan adalah bahan untuk jenis kostum yang bukan dari wayang wong, tetapi busana secukupnya asal diangap dapat membentuk karakter seorang raja. Misalnya, pakaian seorang laki-laki dewasa seperti celana panjang, baju lengan panjang, dasi, mahkota kertas, kalung bunga, selendang, dan wajahnya dirias mirip raksasa dengan gigi taringnya yang menjulur ke atas dan bawah. Hal itu cukup sekedar membentuk karakter seorang raja serakah. Masyarakat yang melihat demonstrasi, baik langsung maupun melalui tayangan televisi, sudah memahami maksudnya.

Pada penampilan tertentu, seperti untuk menggambarkan orang miskin, pinggiran, tertindas, maka penggunaan rias jauh lebih penting (mendominasi) dibanding dengan pemakaian busananya. Dominasi rias terlihat pada sekujur tubuh yang dipenuhi bedhak atau tepung. Dalam penampilan ini, peraga hanya memakai celana pendek ketat warna putih. Celana itu hampir tidak kelihatan karena dominasi rias putih di sekujur tubuh. Dengan kata lain, tidak terdapat tata busana yang dibutuhkan dalam penampilan $h$ - $a$. Namun, ketika peran busana mendominasi berarti riasnya tidak diperlukan. Sebagai contoh, ketika Presiden Amerika Serikat, George W. Bush, berkunjung ke Australia didemonstrasi oleh ratusan ribu rakyat Australia. Dalam demonstrasi tersebut ditampilkan $h$ - $a$ yang menggambarkan tokoh George W Bush mempergunakan busana nasional (celana panjang, jas, baju, dan dasi). Wajah pemeran George W. Bush sama sekali tidak memerlukan rias karena ia memakai topeng.

Di era Orde Baru pun pernah terjadi, busana yang dipakai dalam $h-a$ adalah celana dalam dan 'BH'. Bahkan, celana dalam dipakai sebagai penutup kepala (topi). Tetapi, cara ini dikritik habis-habisan oleh HMI, karena dianggap porno dan kurang etis. Atas kritik tersebut, busana dalam penampilan $h$ - $a$ diadakan pembenahan, yaitu celana dalam diganti dengan celana cinde, atau jenis celana lain yang dapat menutup aurat laki-laki (bagian pusat, kemaluan, sampai lutut tertutup).

5. Panggung

Panggung pertunjukan pada umumnya berbentuk pendhapa, proscenium, atau arena. $H-a$ dalam demonstrasi massa di Yogyakarta belum pernah menggunakan panggung bentuk pendhapa dan proscenium. H-a lebih banyak menggunakan panggung berbentuk arena. Panggung arena bisa berupa jalan raya, lapangan, lembah, pinggir sungai, pantai, lereng gunung, sawah, tegal, dan halaman gedung. Bahkan, dapat menggunakan trap yang telah disiapkan atau sejenis alat pengatur suara penyanyi agar terdengar lebih jernih dan jelas. Jenis yang biasa dipakai yakni merek "Peave" 8 chanel minimum 800 watt. Echo adalah sejenis alat penghasil getaran suara (vibrasi) sehingga suara terdengar bergaung atau memberi efek gema. Jenis yang biasa dipakai adalah merek "Roland". Power adalah sejenis alat yang berfungsi mengeraskan suara agar terdengar sampai radius yang lebih luas. Jenis yang biasa digunakan adalah merek " $\mathrm{H} / \mathrm{H}$ " berkekuatan minimal 800 watt. Sedangkan loud speaker, loud speaker control dan microphone adalah alat bantu mengeluarkan suara sehingga terdengar jauh sekali.

4. Pemain dan Artis

Para pemain Organ Tunggal sebagian adalah bekas anggota Grup Band dari kalangan dewasa, dan sebagian lagi dari kalangan anak muda yang kebanyakan dari mereka dijuluki pemain Organ Tunggal 'dadakan' atau 'karbitan' yang belajar instrumen tersebut dalam waktu yang sangat singkat. Sebenarnya yang dituntut dari seorang pemain Organ Tunggal bukan hanya mereka yang punya kemampuan musikal saja tetapi juga harus pandai mengendalikan program musik yang terdapat di dalamnya. Secara umum ada tiga sistim atau cara permainan yang dipakai para pemain Organ Tunggal di Sumatera Barat. Sistim permainan tersebut adalah: sistim manual, sistim komposer dan sistim sequenser (Santhi, 2001: 39). Sistim manual adalah sistim yang murni mengandalkan kemampuan pemain menggunakan fasilitas musik sesuai dengan petunjuk yang tersedia pada panel dan layar monitor. Sistim permainan seperti ini sangat baik untuk melatih dan meningkatkan kemampuan musikalitas pemain di samping ia harus pula menguasai kecakapan dalam mengoperasikan alat musik tersebut. Sistim ini sama sekali tidak menggunakan disket komputer karena secara utuh hasil musik yang dihasilkan merupakan hasil dari kemampuan kreatifitas pemain dalam memadukan semua unsur-unsur yang ada pada program tersebut, termasuk dalam membuat intro, interlude dan coda lagu dalam mengiringi lagu para penyanyi. Cara permainan organ yang menggunakan sistim komposer dalam hal ini pemain menggunakan disket musik atau disket komputer karena pertimbangan beberapa jenis irama dan karakteristik musik yang hendak diiringi tidak terdapat di dalam instrumen tersebut. Jenis irama musik seperti Dangdut, Gamaik dan lagu pop Minangkabau adalah contoh irama musik yang tidak terdapat dalam program Organ tersebut, untuk itu dibutuhkan disket musik yang dibuat sendiri sebelumnya kemudian pemain tinggal mencocokannya dengan nada dasar penyanyi yang akan diiringinya. Sistim ini juga menuntut kemampuan musikalitas pemain Organ dalam mengiringi lagu para penyanyinya karena fasilitas yang terdapat dalam disket musik tersebut hanya terbatas pada irama dan tempo musiknya saja, sedangkan untuk membuat intro, interlude dan coda lagu tetap harus dibuat sendiri oleh pemain. Sistim permainan ketiga adalah sistim sequenser yang menempatkan pemain tidak lebih sebagai operator saja karena sistim permainan ini telah terprogram secara utuh dalam disket komputer mulai dari pemberian intro, 
merupakan simbol kematian atau kehancuran, keberakhiran, dan kemandegan. Ketika kran demokrasi masih tertutup di era Orde Baru beserta pemerintahan Soeharto yang dirasakan cukup represif, para aktivis sering memuntahkan rasa kekecewaannya dengan melakukan demonstrasi dengan menggelar $h$ - $a$ dengan mengetengahkan keranda bertuliskan demokrasi. Keranda itu melambangkan matinya demokrasi di Indonesia.

Dalam sebuah demonstrasi yang diikuti oleh massa, keranda biasanya diusung oleh empat orang berpakaian hitam-hitam dan bertopeng, atau kadangkadang sekujur tubuhnya dibalut kertas dan dirias putih. Arak-arakan massa berbaris dengan tertib, sedang barisan paling depan adalah kelompok $h-a$ yang menyajikan keranda diusung empat orang. Demonstrasi biasanya dilakukan dengan long march, dan selalu mendapatkan perhatian dari masyarakat pengguna jalan.

Di Yogyakarta demonstrasi seperti itu sering dilakukan, mulai dari Bunderan UGM, menyusuri jalan-jalan, sampai akhirnya berhenti di depan gedung DPRD di jalan Malioboro. Di tempat itu para pemimpin demonstras mengadakan orasi yang diamini oleh massa dengan terikan yel-yel tertentu. Sementara itu, $h$ - $a$ dengan menampilkan keranda melakukan unjuk kebolehan di tengah-tengah massa demonstran.

Properti yang juga sering digunakan dalam $h-a$ adalah tali. Properti itu mudah dicari dan hampir setiap demonstran pasti punya. Kadang-kadang tali itu berasal dari meminjam kepada teman mahasiswa dari unit kegiatan Pramuka. Tali pramuka terbuat dari benang, tidak kaku, dan tidak berat, sehingga mudah untuk dibawa ke mana-mana. Tali tersebut biasanya digunakan untuk mengikat, membelenggu (Jawa: mbanda), atau menyiksa peraga $h-a$.

Jumlah peraga $h-a$ bisa lebih dari satu orang. Penampilan $h$ - $a$ merupakan simbol kelompok masyarakat yang sedang terbelenggu, tidak bebas, dan tidak boleh melakukan kegiatan apa pun. Yang lebih ekspresif lagi, ketika seorang peraga $h$ - $a$ yang diikat tali, ternyata masih juga dikendalikan dengan tali sekitar 5 meter oleh peraga yang lain.

Satu hal yang dinilai cukup positif bahwa $h$ - $a$ dalam berbagai demonstrasi di Yogyakarta tidak pernah mempergunakan properti ban untuk dibakar di tengah jalan seperti halnya $h-a$ di kota-kota lain. Peniadaan pembakaran ban ini dimaksudkan agar $h-a$ tidak merusak jalan yang beraspal dan mencemari lingkungan kota Yogyakarta. Namun, dalam hal bakar-membakar, $h$ $a$ di Yogyakarta cukup sering membakar bendera negara lain yang menjadi sasaran demonstrasi, seperti Australia, Israel, dan Amerika Serikat beserta gambar kepala negaranya.

\section{Gerak}

$H$ - $a$ di Yogyakarta tidak banyak mengeksploitasi gerak-gerak tari tradisi. Menurut pengalaman para peraga $h-a$ dari komunitas mahasiswa seni rupa, gerak tidak menggunakan arena pertunjukan yang terlalu luas, dan dapat pula menciptakan pertunjukan musik layaknya sebuah penampilan grup Band.

\section{Pandangan Masyarakat Padang terhadap Eksistensi Organ Tungga}

Dalam perkembangannya yang telah memasuki usianya lebih dari waktu dua dasawarsa belakangan ini di Padang, Organ Tunggal telah membuktikan dirinya bahwa ia dapat diterima secara umum oleh sebagian besar warga masyarakatnya. Namun berdasarkan observasi dan wawancara yang penulis lakukan dengan beberapa nara sumber selama penelitian lapangan, dalam menyikapi perkembangan Organ Tunggal ini direspon oleh masyarakat dalam dua versi, yakni menerima atau menolak. Di satu sisi masyarakat menerimanya atau menyadari bahwa eksistensi Organ Tunggal di Minangkabau adalah sebagai salah satu bagian permainan rakyatnya dan diterima sebagai konsekwensi logis dari sikap dan pola hidup masyarakatnya yang mobile dan yang selalu terbuka terhadap perkembangan zaman terutama terhadap pengaruh dari budaya luar baik yang disengaja eksistensinya oleh pihak asing atau pun tanpa disadari telah dibawa atau diadopsi sendiri oleh masyarakatnya. Di sisi lain juga masyarakat menolak eksistensinya dengan alasan ingin tetap mempertahankan eksistensi kesenian tradisional mereka sebagai warisan budaya yang telah ada sebelumnya dan harus dilestarikan dari masa ke masa. Masyarakat kota Padang secara umum dapat menerima baik kehadiran Organ Tunggal sebagai bagian dari perkembangan salah satu jenis permainan rakyatnya sampai saat ini, dipakai sebagai dalam memeriahkan berbagai acara dalam kegiatan sosial masyarakatnya dan menjadi pertunjukan musik utama yang digunakan dalam memeriahkan acara Baralek di Padang. Berdasarkan observasi dan wawancara yang penulis lakukan selama penelitian berlangsung didapati masyarakat yang mendukung kehadirannya terdiri dari semua golongan atu kelompok, mulai dari kelompok masyarakat dari usia muda sampai pada kelompok usia tua. Di samping mendapat dukungan juga mendapat sorotan atau kritikan dari warga masyarakat kota Padang, terutama dari kalangan orang dewasa, dari para orang tua atau dari para ulama yang fanatik dengan ajaran adat dan agama Islam. Kritik dilontarkan oleh masyarakat karena dalam penampilannya terdapat hal-hal yang tidak sesuai dengan agama dan adat istiadat Minangkabau, seperti penyajian materi musik yang tidak menggambarkan warna lokal Minangkabau yang disertai oleh perilaku seronok para artis Organ Tunggal dalam pertunjukan yang dilaksanakan pada malam hari. Kadangkala dalam pertunjukan disertai juga dengan penggunaan minuman keras yang dilakukan oleh anggota grup Organ Tunggal itu sendiri. Tak jarang pula terjadi perkelahian antar warga masyarakat dalam setiap penampilannya.

\section{Bentuk Pertunjukan Organ Tunggal dalam Acara Baralek}

\section{Waktu pertunjukan}

Umumnya waktu pertunjukan Organ Tunggal dalam acara Baralek dilaksanakan dalam dua waktu, yakni sehari sebelum hari Baralek yakni pada hari 
biasa dilakukan adalah mengadakan pertemuan para personil, kemudian mengadakan kesepakatan-kesepakatan tentang ekspresi dan kaitannya dengan para demonstran, agar nantinya mudah diterapkan di lapangan. Namun, dalam sisi tertentu sebelum pementasan, $h-a$ juga diadakan latihan meskipun hanya sekali atau dua kali. Hal itu ditempuh agar terjadi kekompakan di dalam berekspresi, lebih-lebih jika $h$ - $a$ diragakan oleh banyak orang (kelompok), dan ternyata membutuhkan kekompakan dalam hal ekspresi gerak. Maka, kesulitan akan terjadi jika gerak tidak dilatih terlebih dahulu.

Dalam suatu demonstrasi massa, fungsi $h-a$ lebih bersifat menerjemahkan tujuan demonstrasi. Hal itu diketahui ketika elemen verbalitas dalam suatu demonstrasi diekspresikan melalui orasi dan pusisi, di belakangnya ditampilkan $h a$. Dalam hal itu $h-a$ berfungsi sebagai ilustrasi dari ekspresi verbalitas. Meskipun, $h$ - $a$ juga dapat berdiri sendiri sebagai bentuk demonstrasi yang berbentuk pertunjukan, tidak disertai massa, dan verbalitas. Baik sebagi ilustrasi maupun berdiri sendiri, $h$ - $a$ tampil seacara all-out, yakni tampil secara serius dan ekspresinya ditampilkan habis-habisan.

Di dalam demonstrasi sering terlontar kata-kata kasar, tajam, dan keras sebagai bentuk kritik terhadap pihak penguasa yang dianggap dholim (rusak). Dampaknya aparat keamanan yang menjaga demostrasi langsung mengungkapkan kemarahannya. Untuk mengatasi hal itu, memperhalus bentuk demonstrasi dengan cara menampilkan $h$ - $a$. Seni mempunyai sifat-sifat kehalusan yang mampu meredam atau mengendapkan perasaan.

$H$ - $a$ lebih mudah ditangkap oleh kalangan masyarakat awam. Hal itu disebabkan dengan mendengarkan orasi atau baca puisi, sering isinya sulit untuk ditangkap. Tetapi kehadiran $h$ - $a$ di mata mereka merupakan bentuk representasi dan substansi dari ekspresi demonstrasi. Terlebih kata-kata yang diungkapkan oleh para demonstran yang rata-rata dari kalangan mahasiswa relatif intelek dan abstrak. Dengan demikian, kehadiran $h$ - $a$ lebih memudahkan masyarakat umum dalam menangkap substansi dari suatu demonstrasi.

\section{DAFTAR PUSTAKA}

Basrowi dan Sukidin. 2003. Teori-teori Perlawanan dan Kekerasan Kolektif. Surabaya: Insan Cendekia.

Becker, J. 1980. Traditional Music in Modern Java Gamelan in a Changing Society. Honolulu: The University Press of Hawai.

Bouvier, H. 2002. Lebur Seni Musik dan Pertunjukan dalam Masyarakat Madura. Jakarta: Yayasan Obor Indonesia.

Cahyadi, K. 1994. "Demonstrasi sebagai Media Kritik". Basis, Edisi Maret 1994. Feldman, E. B. 1967. Art as Image and Idea. New Jersey: Prentice-Hall, Inc. Mirsel, R. 2004. Teori Pergerakan Sosial: Kilasan Sejarah dan Catatan

Bibliografis. Magelang: Resist Book. seluruh dunia waktu itu (Aprianti, 1992: 19). Kemunculan alat musik organ yang dipakai dalam pertunjukan Organ Tunggal di Minangkabau telah merangsang pula seniman lokal untuk berkarya melalui instrumen musik ini. Banyak karya musik baru dalam bentuk lagu populer yang diciptakan oleh para pencipta lagu Minangkabau menggunakan fasilitas dan sarana musikal Organ Tunggal ini. Sehubungan dengan istilah musik populer dalam musik diartikan sebagai musik yang seyogyanya mudah untuk dipahami (dan mungkin juga mudah untuk ditampilkan) oleh kebanyakan orang dan apresiasinya hanya membutuhkan sedikit atau tanpa pengetahuan mengenai teori musik dan teknik musik (Lamb dalam Sadie, 1980: 87). Mack (1995: 11-12) membedakannya antara istilah populer yang berkaitan dengan kesan yang berhubungan dengan masyarakat atau rakyat, dengan istilah populer sebagai kata sifat tentang segala sesuatu yang diketahui kebanyakan orang, disukai kebanyakan orang dan mudah dipahami oleh rakyat. Pada penampilan musik Organ Tunggal sebagai sebuah bentuk seni pertunjukan yang bersifat populer hal yang disebutkan oleh Mack dan Lamb juga terlihat. Hal yang tampak sebagai kesan yang merakyat dapat dilihat dari cara penyajian lagu-lagu dari para penyanyi Organ Tunggal yang sudah dikenal oleh masyarakat luas atau bukan dari jenis lagu-lagu serius yang sulit dibawakan orang. Dari segi garapan musik yang ditampilkan juga terkesan sangat simpel dan praktis dengan memilih jenis irama musik yang juga sudah dikenal oleh masyarakat luas.

Pertunjukan Organ Tunggal disebut sebagai hasil produk teknologi canggih dan budaya massa karena organ yang dipakai dalam pertunjukan musik Organ Tunggal di Padang merupakan alat musik hasil produk teknologi canggih yang menggunakan sistim komputerisasi. Melalui sistim perdagangan bebas alat musik organ tersebut didistribusikan ke seluruh dunia termasuk ke Minangkabau. Peran media massa yang ikut mempromosikannya memberi peluang pula untuk berkembang menjadi budaya massa. Menurut Lull, (1995: 70) media massa tidak hanya melintasi batas-batas geografis, tetapi juga batas-batas kelas, ras, budaya, politik, pendidikan, dan jenis kelamin, dalam rangka mendistribusikan-sebagai produk yang disampaikan secara rutin-hiburan dan informasi yang menanamkan dan menyegarkan sudut pandang dan cara pemahaman tertentu. Media massa membantu mematahkan jarak antara yang makrososial dan mikrososial, membawa tema-tema publik ke dalam lingkungan privat tempat dia memasuki dan dipengaruhi oleh kondisi, orientasi, otoritas dan kebudayaan lokal (Lull, 1995: 71).

2. Perkembangan Organ Tunggal di Padang

Tahun 1983 adalah awal sejarah perkembangan Organ Tunggal di Padang. Arman salah satu mantan musisi grup Band Ganto Minang yang telah berkiprah sejak tahun 1972 di Padang mengatakan: munculnya grup Organ Tunggal disebabkan karena kejenuhan dan rasa bosan dari sebagian anggota Grup Band di Padang (Wawancara, 10 November 2006). Di samping kejenuhan dan rasa bosan dari sebagian anggota grup Band tersebut juga disebabkan karena bunyi musik 
pertunjukan musik Organ Tunggal. Pertunjukan musik Organ Tunggal ini digunakan oleh setiap keluarga baik masyarakat perkotaan maupun masyarakat di pedesaan Bahar (2003: 243).

Dalam perkembangannya pertunjukan musik Organ Tunggal mendapat tanggapan yang luar biasa dari masyarakat Minangkabau. Pertunjukan musik Organ Tunggal tidak saja dipakai dalam acara Baralek tetapi juga menjadi sarana hiburan dalam berbagai kegiatan sosial budaya masyarakat Minangkabau lainnya seperti dalam acara pengangkatan penghulu, perayaan hari besar nasional seperti acara HUT kemerdekaan, hari Sumpah Pemuda, hari raya Idul Fitri dan lain sebagainya. Di Padang pertunjukan musik Organ Tunggal menjadi pertunjukan musik utama atau yang paling dominan dalam memeriahkan acara Baralek di samping penggunaan kesenian tradisional setempat yang juga masih digunakan sampai saat ini namun prosentase kehadirannya makin berkurang dengan adanya suguhan seni pertunjukan musik Organ Tunggal yang lebih meriah dan spektakuler dalam memeriahkan acara Baralek (Tulus, 2004: 109). Kehadiran pertunjukan musik Organ Tunggal mempunyai peranan yang cukup penting dalam kehidupan sosial masyarakat Minangkabau terutama dipakai sebagai sarana hiburan utama dalam menyemarakkan acara Baralek di Minangkabau. Fenomena ini cukup menarik untuk dijadikan sebagai objek penelitian karena penelitian musik sangat berguna untuk mendapatkan pengertian suatu kebudayaan secara keseluruhan. Sebagaimana yang diungkapkan Bos (1994: 95) bahwa musik merefleksikan makna kebudayaan, musik sebagai interpretasi kebudayaan. Dan menurut Kleden (1994: 181), musik mempunyai tiga referensi, yakni: (1) referensi kepada komposernya, (2) referensi kepada situasi sosiokultural tempat musik dilahirkan, dan (3) referensi kepada pendengarnya.

\section{B. Keberadaan Organ Tunggal di Minangkabau}

\section{Konsep Pertunjukan Organ Tunggal}

Segala aktifitas kesenian di Minangkabau disebut dengan istilah pamainan rakyaik atau permainan rakyat. Permainan rakyat Minangkabau perannya cukup besar dalam mendukung kemeriahan suatu pesta adat dan dalam perjalanannya mengalami berbagai perkembangan karena sifatnya mobile atau terbuka dan fleksibel sebagai milik umum. Gambaran permainan rakyat Minangkabau yang bersifat terbuka dan fleksibel ini diungkapkan oleh Navis (1984: 263) sebagai berikut:

Permainan rakyat Minangkabau sebagai kesenian rakyat bersifat terbuka, oleh rakyat dan untuk rakyat, sesuai dengan sistim masyarakatnya yang demokratis yang mendukung falsafah persamaan dan kebersamaan antara manusia. Oleh sebab sifatnya yang terbuka sebagai milik umum, maka permainan rakyat Minangkabau mudah berubah akibat persentuhannya dengan kebudayaan luar. Pengertian berubah bisa diartikan sebagai berkembang, memperkaya atau memperbanyak. Persentuhannya dengan kebudayaan luar ialah akibat perannya 
